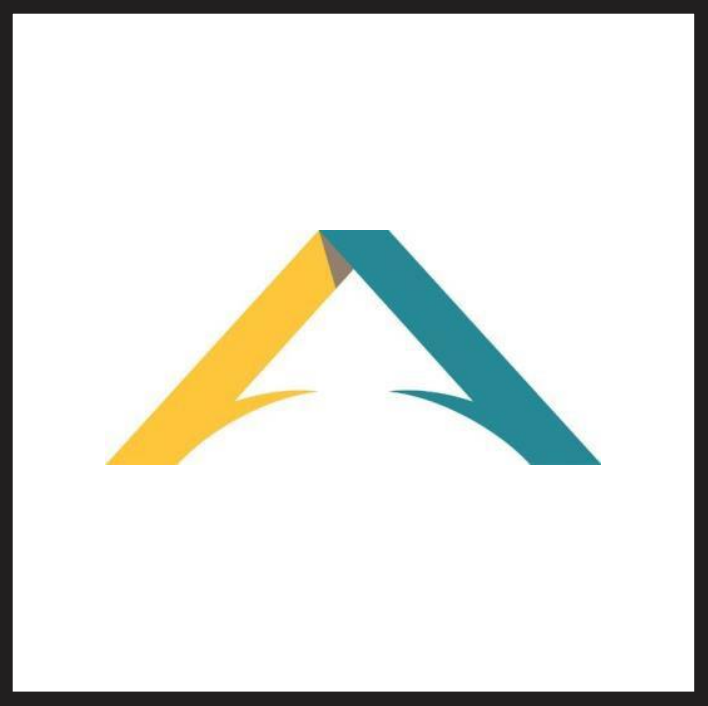

Revista

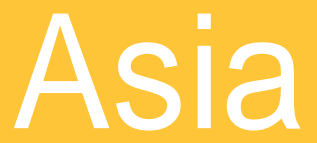

América

Latina

ISSN 2524-9347

Grupo de Estudios sobre Asia y América Latina Instituto de Estudios de América Latina y el Caribe Universidad de Buenos Aires

(c)

EU

DE BA 
Gasquet, Axel and Gorica Majstorovic Ed. Cultural and Literary Dialogues Between Asia

and Latin America

CHISU TERESA KO

\section{GASQUET, AXEL AND GORICA MAJSTOROVIC ED. CULTURAL AND LITERARY DIALOGUES BETWEEN ASIA AND LATIN AMERICA}

Palgrave Macmillan, 2021. 274 pp.

\section{Chisu Teresa Ko}

Ursinus College

The edited volume Cultural and Literary Dialogues Between Asia and Latin America edited by Axel Gasquet and Gorica Majstorovic is an important addition to the growing fields of Asian Latin American and Transpacific Studies. While the connections between these regions have been understudied, their historical contacts run deep. In their informative and succinct introduction, Gasquet and Majstorovic frame these contacts within the broader context of the "first globalization on a planetary scale and the first prefiguration of the subsequent modernity" that initiated "prolonged intra-colonial connections between Asia, America, and Europe." The volume attempts to reflect the vast historical, geographic, and cultural diversity encompassed within these regions and their histories of contact. The contributions are from scholars based in Asia, Europe, the United States, and Chile and address an impressive range of gazes, exchanges, expressions, movements, historical periods, and geographic regions, from Hispanic-Filipino intellectual Trinidad Hermenegildo Pardo de Tavera's travel writings about Argentina in the early twentieth century to contemporary literature on hybrid Asian and Latin America identities, the reception of Chilean literature in twentieth-century South Korea and diasporic Nikkei experiences in the Americas, among others. The volume, published in English, is divided into four parts each consisting of three or four chapters.

The three chapters included in the first section titled "Asian Hybrid Identities and Latin American Transnational Narratives" analyze the works of contemporary Latin American writers who explore, through fiction and nonfiction, complex hybrid identities: Chinese and Argentine in Federico Jeanmarie's Tacos altos (2016); Chilean and Palestinian in Lina Meruane's Volverse palestina; Mexican, Syrian, and Lebanese in Memoria de Libano (2003) by Carlos Martínez Assad and Casa Damasco (2013) by Maura Soto Antaki. The contributors-María Montt Strabucchi, Lila McDowell Carlsen, and Verónica Torres - trace perceptively how these complex hybrid identities and expressions are shaped by physical and cultural transnational comings and goings. Torres's assertion that Memoria de Líbano and Casa Damasco "showcase a different conception of Mexican identity" or Montt Strabucchi's observation that Tacos 
Gasquet, Axel and Gorica Majstorovic Ed. Cultural and Literary Dialogues Between Asia

and Latin America

CHISU TERESA KO

altos "interrupts discourses of homogeneity in Latin America" hold true for the other works examined in this section, all of which push the boundaries of national, diasporic, and individual identities through transnational experiences and imaginaries.

Part II, "Reception and Translations of Latin American Writers in Asia," offers important critical contributions and innovative persepctives. Ignacio M. Sánchez Prado focuses on the essay-memoir La casa del dolor ajeno (2015) by Mexican writer Julián Herbert to address the historical "erasure of Asia" that correlates to the structures of Mexican capitalism and Hong Kong director Wong Kar-Wai's film Happy Together (1997) to consider the "joint historical experience of the neoliberal condition" that Asia and Latin America share. Sánchez Prado proposes that in order to avoid practices of continued historical erasure, scholarship on Asia-Latin America should revise theoretical tools such as Orientalism "to break them away from their grounding in the epistemological practices of the European imperial enterprise" and to examine, instead, direct contacts and mutual readings between the peripheries.

Woo Suk-kyun's enlightening chapter on the reception of Latin American literature in twentieth century South Korea does just that. Woo traces in fascinating detail the historical, ideological, intellectual, and commercial contexts in South Korea and beyond that led to the dissemination of contemporary Latin American literature in South Korea, and in particular, the popularity of literary works that portray the Chilean coup. While the unique importance of the Chilean coup in the South Korean cultural imaginary can be explained by parallel late-twentieth century histories of military regimes, coups, and massacres, Woo traces a complex web of genealogies of intellectual influences and literary translations. These include the first translations of Pablo Neruda's poems in the 1960s and 70s, translations of books on liberation theology and dependency theory in the 1970s, and the emergence of antiAmericanism and Third World consciousness. Puo-An Wu Fu concludes this section with a chapter on the novel Mongolia (2015) by Peruvian Tusán writer Julia Wong and the short story "El testigo chino" by Anna Kazumi Stahl, a Japanese American author who writes mostly in Spanish and has resided in Argentina for almost three decades. The chapter examines the literary strategies of the two works-focused on cultural and linguistic translations and "real-life bilinguaging"- that help construct "a readable world."

The chapters in Part III entitled "Diffraction Worlds of Nikkei Identities" reveal the heterogeneity of Asian experiences and identities as well as the cultural imaginary produced around them. Sigeko Mato analyzes Peruvian author of Japanese descent Carlos Yuhsimito del Valle's short story "Ciudad de Cristal" about a Japanese Peruvian boy in an internment camp in Texas. Seth Jacobowitz examines the crisis and eventual emergence of a "new diasporic consciousness" within the Japanese communities in Brazil during World War II. The chapter 
Gasquet, Axel and Gorica Majstorovic Ed. Cultural and Literary Dialogues Between Asia

and Latin America

CHISU TERESA KO

brings into light the short story "Revenge" by Japanese immigrant writer Sugi Takeo which, according to Jacobowitz, has remained in "near-total obscurity." This story, published in 1938 in a Japanese-language literary journal based in Sao Paolo, is put in conversation with contemporary Brazilian film Dirty Hearts (2011). Ignacio López-Calvo examines the "monstrifying" of Japanese immigrants in Peru in Jorge Salazar's novel La medianoche del japonés (1991) and of Chinese Mexicans in Juan José Rodríguez's Asesinato en una lavandería china (1996). By reading these novels together, this chapter highlights not only the differing historical circumstances and experiences of Japanese and Chinese immigrants in Latin America but also the entanglements of Sinophobia, Nipponophobia, and the "national (mestizo) projects."

The first two chapters of Part IV, "Crossroads of Asia-Latin American Narratives and Travel Writing," focus on the connections between the Philippines and Latin America. Jorge Mojarro compares José Rizal's canonical novel Noli me tangere (1887) to key Latin American foundational fictions. Axel Gasquet's chapter illuminates readers on one among "very rare" travelogues of Latin America by Filipino intellectuals. This chapter focuses on Trinidad Hermenegildo Pardo de Tavera's "Argentine Memories," published in Spanish two years after his visit to Argentina in 1914. Gasquet shows how Pardo de Tavera's observations-on Argentina's social life, political and social structures, and predictions about the future-were informed by his status from a distinguished Hispanic-Filipino family, an acritical vision of Argentina's "path to modernity," as well as other testimonials about Argentina's 1910 centennial celebration that focused on this nation's liberal "successes."

This section also includes Everton V. Machado's chapter on Brazilian poet Cecília Meireles's testimony to her visit to India in 1953 and Estefanía Bournot's examination of Colombian writer Hector Abad Faciolince's Oriente empiza en el Cairo (2001) and Brazilian Bernardo Carvalho's Mongolia (2003). These last two chapters return to the question of the possibility of a south-south epistemology raised throughout the volume. Bournot detects in Abad and Carvalho's contemporary novels the persistence of colonial and Orientalist images of the East as a "static object, deprived of subjectivity and declared incapable of possessing any prospective or retrospective dimensions." By contrast, for Machado, even if Meireles's south-south dialogue was inscribed within the European Orientalist tradition and was limited by a unilateral direction from West to East, the poet's attempts to connect the peripheries and integrate "the voice of the Other" should not be overlooked.

As titles rarely do, some of the titles of the four sections do not entirely reflect the contents of their chapters. But rather than a shortcoming, this only underscores the breadth, scale, and reach of this volume that includes scholarship of multiple and layered interests, subjects, and perspectives that cannot be reduced to a title or deservedly summarized in a brief book review. 

